Natural Hazards and Earth System Sciences (2003) 3: 647-662

(C) European Geosciences Union 2003

\title{
Regional-scale GIS-models for assessment of hazards from glacier lake outbursts: evaluation and application in the Swiss Alps
}

\author{
C. Huggel, A. Kääb, W. Haeberli, and B. Krummenacher \\ Glaciology and Geomorphodynamics Group, Department of Geography, University of Zürich, 8057 Zürich, Switzerland
}

Received: 9 January 2003 - Accepted: 3 April 2003

\begin{abstract}
Debris flows triggered by glacier lake outbursts have repeatedly caused disasters in various high-mountain regions of the world. Accelerated change of glacial and periglacial environments due to atmospheric warming and increased anthropogenic development in most of these areas raise the need for an adequate hazard assessment and corresponding modelling. The purpose of this paper is to provide a modelling approach which takes into account the current evolution of the glacial environment and satisfies a robust first-order assessment of hazards from glacier-lake outbursts. Two topography-based GIS-models simulating debris flows related to outbursts from glacier lakes are presented and applied for two lake outburst events in the southern Swiss Alps. The models are based on information about glacier lakes derived from remote sensing data, and on digital elevation models (DEM). Hydrological flow routing is used to simulate the debris flow resulting from the lake outburst. Thereby, a multiple- and a single-flow-direction approach are applied. Debris-flow propagation is given in probabilityrelated values indicating the hazard potential of a certain location. The debris flow runout distance is calculated on the basis of empirical data on average slope trajectory. The results show that the multiple-flow-direction approach generally yields a more detailed propagation. The single-flowdirection approach, however, is more robust against DEM artifacts and, hence, more suited for process automation. The model is tested with three differently generated DEMs (including aero-photogrammetry- and satellite image-derived). Potential application of the respective DEMs is discussed with a special focus on satellite-derived DEMs for use in remote high-mountain areas.
\end{abstract}

\section{Introduction}

\subsection{Objectives}

The present paper aims at providing a tool for first-order assessments of hazards from glacier lake outbursts. A first-

Correspondence to: C. Huggel (chuggel@geo.unizh.ch) order hazard assessment is understood as a first hazard estimate and assessment, including modelling studies at regional scale (covering an area of about $5 \times 10^{1}$ to $1 \times$ $10^{4} \mathrm{~km}^{2}$ ). Thus, a conclusive assessment usually cannot yet be achieved.

Accelerated changes of glacial and periglacial environments due to atmospheric warming make a continuously updated information base on a regional scale a prerequisite for such hazard assessments. Remote sensing techniques in combination with Geographic Information Systems (GIS) are particularly capable to satisfy these needs. Two models are developed here, both are based on remote sensing data and the application of different topography-based hydrological flow-routing algorithms. The objective of the study is to evaluate the models' performance for regional modelling of glacier lake outburst hazards. Corresponding to digital elevation models (DEM) of different sources and resolution, model application on varying scale levels is analysed. A focus is thereby set on the use of satellite data-derived DEMs. Specifically, the recently launched ASTER sensor opens new perspectives for DEM generation in poorly documented high-mountain regions worldwide (Kääb, 2002). The potential use of the models presented here may be a considerable advance for hazard assessments in remote regions such as the Andes, Himalayas, or Karakorum. The paper therefore attempts to evaluate the models in combination with satellite data for regional use, or, in other words: to which extent the models can be applied at different scale levels.

The paper first presents two theoretical models of lake outburst debris flows. Due to high data availability, both models are applied at selected test sites in the Swiss Alps. At Täsch, a site of a recent debris flow related to a morainedammed lake failure, both models are evaluated against each other. At the location Gruben, a further site of past glacier lake outburst-floods in the southern Swiss Alps, the influence of different grid cell resolution is investigated. DEMs stemming from different sources (map, aerial photographs, satellite stereo imagery) are thereby used. Model application for the Matter-, Saas valley and Simplon region linking remote sensing and GIS models is shown, and potential as 
well as limitations of corresponding hazard assessments are discussed.

\subsection{Background}

Debris flows from glacier lake outbursts are a threat to people and property in many mountain regions throughout the world. Disasters from sudden lake dam failures have been reported from the Peruvian Andes (Lliboutry et al., 1977; Reynolds, 1992; Ames, 1998), the Himalayas (Vuichard and Zimmermann, 1987; Hanisch et al., 1996; Yamada, 1998; Richardson and Reynolds, 2000), Central Asia (Popov, 1997) and North America (O'Connor and Costa, 1993; Clague and Evans, 1994; Evans and Clague, 1994; Clague and Evans, 2000). Most of these locations lie in remote regions where access and data availability are a major obstacle for qualified hazard assessments. Therefore, a tool for assessing such hazards on a regional level is of significant importance. The European Alps have also been a particular focus of such catastrophic events since they are among the most intensively developed and populated mountain regions (Haeberli, 1983; Chiarle and Mortara, 2001; Haeberli et al., 2001). Strong tourism development in the past decades has led to an increased vulnerability with respect to debris flow events. Additionally, the present trend of atmospheric warming is causing an enhanced glacier retreat and may bring along the formation of new glacier lakes and a shift of hazard zones (Zimmermann and Haeberli, 1992; Evans and Clague, 1994; Haeberli and Beniston, 1998). The European Alps have comparably good data availability and access conditions. Nevertheless, in consideration of increasing environmental and anthropogenic change, there is also a strong need for updated information and corresponding hazard modelling.

Remote sensing and GIS are rapidly developing techniques, possessing the potential to map and model hazards related to lake outburst debris flows with an adequate representation of current high-mountain environmental changes. Although remote sensing techniques have been widely used for surface hydrology (Pietroniro and Leconte, 2000), they have been rarely applied to problems of hazardous glacier lakes. Huggel et al. (2002) developed remote-sensing techniques to automatically detect and map glacier lakes and to assess their hazard potential based on a multiscale approach. Wessels et al. (2002) successfully mapped Himalayan glacier lakes and related parameters. Several studies have demonstrated the potential of GIS for debris flow hazard assessments on a regional scale (Carrara et al., 1995; Zimmermann et al., 1997; Schilling and Iverson, 1997; Heinimann et al., 1998; Iverson et al., 1998; Campbell and Chirico, 1999; Gamma, 2000; Fuchs et al., 2001). GIS is also the ideal platform for the integration of spatial data and remote sensing-derived data. However, no one has previously taken advantage of the promising potential of a combined remote sensing/GIS approach for debris flows from lake outbursts. This study therefore tries to exploit the capabilities of both techniques for assessing the hazards from glacier-lake outbursts on a regional basis (Matter, Saas valley and Simplon region, southern Swiss Alps). Detailed model evaluation is performed at local scale.

\section{Models}

Debris flows from lake outbursts can be described as a medium flowing from a given source (i.e. the glacier lake) down to a certain, varying runout point or area. Algorithms for transferring flow sequentially to lower points or areas are usually called (flow) routing algorithms (Desmet and Govers, 1996). Such algorithms determine the way in which the outflow for a given element or cell will be distributed according to mathematical equations representing processes. A variety of flow-routing algorithms have been proposed, and theoretical advantages and disadvantages for different applications were discussed (Garbrecht and Martz, 1997; Desmet and Govers, 1996; Tarboton, 1997; Meissl, 1998; Liang and Mackay, 2000; Dorren, 2003). In this paper, we use two routing algorithms based on grid DEMs. Grid DEMs are chosen because of their wide availability and use. Other DEM representations such as triangular irregular network (TIN) or contour-based data storage structures are not considered here.

\subsection{Model input data}

Remote sensing data

Detection of the glacier lakes was achieved using a 1998 Landsat Thematic-Mapper scene of $25 \mathrm{~m}$ ground resolution (track 195/frame 28; 31 August 1998; for description of the detection algorithm see Sect. 5). Additionally, an IRS-Pan scene of $5 \mathrm{~m}$ ground resolution (path 25/row $36 \mathrm{C}$, 20 September 1997) was applied for a fusion image and for debris flow mapping support. At Gruben, we used an orthophoto of 1991 infra-red aerial photography to verify the models by debris flow mapping and 1999 aerial photography for DEM generation.

DEMs

Three different DEMs were used for model application: DHM25: The $25 \mathrm{~m}$-gridded DHM25, Level 2, is a commercially available DEM distributed by the Swiss Federal Office of Topography. It entirely covers the area of Switzerland and is therefore suited for regional applications. In the region of interest, the DEM accuracy of DHM25 is given with a vertical error between 4 and $6 \mathrm{~m}$ (Bundesamt für Landestopographie, 2001).

ASTER DEM: Satellite data is of increasing significance for deriving DEMs. For optical remote sensing systems a stereo imagery is required for DEM generation. The ASTER sensor onboard Terra is one of the first to record the stereo image in the same satellite overpass thanks to a separate back-looking sensor (along-track stereo). Acquisition of the stereo imagery at the same date and nearly same time is a great advantage for DEM generation since scene inconsistencies due to different recording time (in the order of days, months or years) can be avoided. Ground resolution 

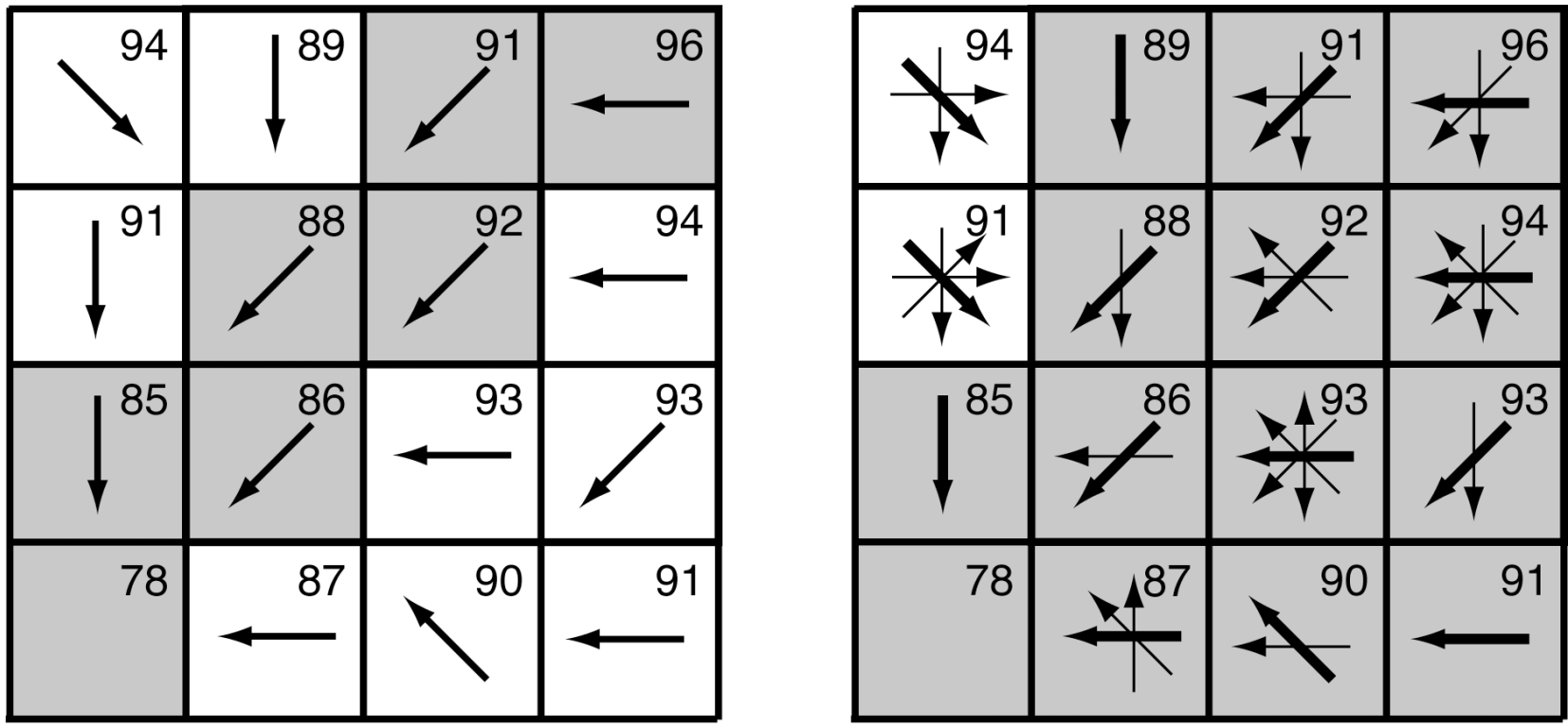

Fig. 1. Modified single-flow- and multiple-flow-direction approaches exemplified on a hypothetical DEM subset. The theoretical elevation values are given in the upper right corner of each cell and refer to the elevation of the cell centre. General flow is from upper right to lower left. Arrows indicate the direction of flow as calculated according to the algorithms. For multiple-flow direction, the major (weighted) flow direction is indicated by bold arrows, further flow directions from the same cell by thin arrows. Shaded cells show areas which would be covered by a debris flow according to the MSF- and MF-models.

of the ASTER stereo channels is $15 \mathrm{~m}$ but DEM resolution is usually set between 25 and $30 \mathrm{~m}$. First tests with ASTERderived DEMs in rugged terrain in the Swiss Alps have shown that the DEM accuracy is in the order of $\pm 18 \mathrm{~m} \mathrm{RMS}$ and $\pm 60 \mathrm{~m}$ RMS for particularly rugged and complex terrain (Kääb, 2002). Problems mainly arise with some mountain peaks and steep slopes exposed to the north which show a high distortion in the $27.6^{\circ}$ back-looking stereo channel.

Aerial photography DEM: The aerial photographs were taken in 1999 at a scale of about 1:20000. Since they were taken for the purpose of investigations in the Gruben area, only the upper and middle part of the debris flow are covered. Digital photogrammetric techniques (Baltsavias et al., 2001; Kääb and Vollmer, 2000) were used to generate a 10 mgridded DEM. Analytically extracted terrain break lines were integrated in the process of DEM generation in order to gain the highest possible degree of detail.

\subsection{Modified single-flow-direction (MSF) model}

One of the earliest and simplest routing method for specifying flow directions is to assign flow from each cell to one of its eight neighbours, either adjacent or diagonal, in the direction of the steepest descent. This method, designated D8 (eight possible flow directions), was introduced by O'Callaghan and Mark (1984) and is still one of the most frequently used (Marks et al., 1984; Jenson and Domingue, 1988; Tarboton et al., 1991; Martz and Garbrecht, 1992). It is furthermore implemented in the GIS software Arc/Info (Environmental Systems Research Institute, ESRI) as a stan- dard for hydrological flow modelling (function 'flowdirection', Jenson and Domingue, 1988). The implementation of the algorithm in a frequently used software system is one of the reasons we chose the D8 method since it greatly eases the application and reproduction of the model.

For use in the model, flow directions were calculated with the DHM25. The DEM was previously corrected for possible sinks which would cause inconsistencies in the calculation of flow directions (fill algorithm according to Jenson and Domingue, 1988). The basic idea then is to simulate the debris flow from the point of initiation downvalley. The central flow line of the debris flow is assumed to follow the direction of steepest descent as calculated by the single-flow-direction algorithm. However, in less steep terrain sections, a debris flow often deviates from the steepest descent direction, and flow spreading and deposition of sediment are observed. A single-flow-direction path cannot accurately model this process. We therefore integrated a function in the model enabling a certain flow diversion. The function 'pathdistance' in Arc/Info was recognized to have the requested functionality. 'Pathdistance' is basically designed for calculating a cost-weighted function for movement between two points (or a set of points) under the assumption of a given resistance (ESRI, 2002). For our purpose, we modified the function in a way that allows the flow to divert from the steepest descent direction up to $45^{\circ}$ on both sides (Fig. 1). A linear function defines that the more the flow diverts from the steepest descent direction the greater is the resistance. The model is thus capable to simulate the different characteristics of debris 
flows in confined channel sections (largely limited spread due to converging flow) and on relatively flat or convex terrain (e.g. debris fans; greater spread due to more diverging flow).

We believe the spread behavior of debris flows on fan-like terrain is best represented by a probability function. The modified 'pathdistance' function yields a cell value which increases downvalley from the location of debris flow initiation (increasing 'cost' distance) and laterally in a $45^{\circ}$-angle from the steepest descent flow path (increasing flow resistance). The ratio of the 'pathdistance' function value and the horizontal distance from each cell to the debris flow source (glacier lake) is interpreted as a function representing probability values: each cell value is related to the probability that this cell be affected by the debris flow:

$$
P_{q}(i)=\frac{H_{(i)}}{P_{a}(i)}
$$

Where $P_{q}(i)$ is the probability-related function for cell $i, P_{a}(i)$ the pathdistance function and $H(i)$ the horizontal distance of cell $i$ to the point of debris flow initiation. $P_{q}(i)$ is not a mathematical probability in a strict sense but can be interpreted in a way of qualitative probability (e.g. colourcoded graphics).

For estimating the runout distance (trajectory length) of the debris flow, a 'worst-case' approach is followed (Huggel et al., 2002). The term 'worst-case' is related here to the probable maximum runout. Studies have analysed the runout characteristics of debris flows from glacier/morainedammed lakes in the European Alps. It has been found that average slope angles $a$ related to maximum runout distance do not fall below $11^{\circ}(\tan a=0.19)$ (Haeberli, 1983; Huggel et al., 2002). The average slope is thereby defined as the slope of a line between the starting and end point of an outburst event to the horizontal. Implementation of the average slope concept is achieved within the Arc/Info functionality: for each cell potentially affected by the debris flow the ratio between the vertical drop and the horizontal distance along the curving flow path to the glacier lake is calculated. The modelled debris flow is stopped when the average slope of $11^{\circ}$ is reached. The average slope is applied irrespective of the streamflow connectivity. However, if the debris flow reaches a receiving stream in the main valley, the $11^{\circ}$ might no longer be raised, and has to be reassessed.

For model evaluation it is important to stress that the MSFmodel has not strictly a physical basis of debris flow behaviour. There is a constraint of the D8 method as well as of the general grid structure. The diversion function implemented in the model can only broadly represent the flow characteristics but is nevertheless fairly reasonable. Problems with the model mainly arise with errors in the flow directions which originate from errors in the DEM rather than from the D8 algorithm. Errors in the DEM or insufficient DEM ground resolution can cause the flow to divert substantially from the steepest descent path. Although at some locations this may first appear unrealistic, such points of diversion can represent critical locations for the hazard assess- ment and should be carefully checked. Model verification has shown that such critical points are mainly present at sections of temporary debris flow deposition on convex terrain and/or with poorly defined channel geometry not adequately represented in the DEM.

\subsection{Multiple-flow-direction (MF) model}

A single-flow-direction method such as the D8 algorithm has limitations arising from the discretization of flow into only one of eight possible directions (cardinal and diagonal) (Costa- Cabral and Burges, 1994; Tarboton, 1997). As an attempt to overcome these deficiencies, multiple-flowdirection approaches have been proposed (Freeman, 1991; Quinn et al., 1991). These partition flow fractionally from a cell to each lower neighbour by weighting flow in proportion to slope (Fig. 1). In order to test a multiple-flowdirection approach for modelling debris flows from glacier lake outbursts, we chose the algorithm by Quinn et al. (1991). They implemented a multiple-flow-direction algorithm in the TOPMODEL concept (Beven and Kirkby, 1979; Beven, 1997; Quinn et al., 1997) introducing a geometric weight factor to calculate the fraction of flow draining through a neighbouring cell:

$$
A_{i}=A \cdot \frac{\tan \beta \cdot L_{i}}{\sum_{i=1}^{k} \tan \beta \cdot L_{i}}
$$

where $A_{i}=$ fraction draining through neighbour $i\left(\mathrm{~m}^{2}\right), A=$ upslope area accumulated in the current cell $\left(\mathrm{m}^{2}\right), \beta=$ slope towards neighbour $i, L_{i}=$ geometric weight factor $(0.5$ for cardinal and 0.354 for diagonal directions) for flow towards neighbour $i$; and $k=$ total number of downhill directions.

For use in the lake outburst debris flow model, we modified the FORTRAN code by Beven (1995) which calculates the flow distribution for a given catchment according to Eq. (2). Originally, all starting values for $A$ in the catchment are set to the grid cell area (Beven 1995). For all cells, the catchment area draining through this cell is thus calculated. In our model, however, we want to propagate water downstream only from one point source (point of potential lake dam breach) and thus avoid calculation in areas unaffected by the debris flow. Hence, we set $A=0$ (or a value insignificantly larger than 0 according to algorithm requirements) for all grid cells except for the cell where the lake outburst starts (determination of the start location is discussed in Sect. 4).

The starting cell value would theoretically be equal to the volume of water (in cubic meters) stored by the lake (assuming a full lake drainage). The flow divergence in the model, however, is usually strong, a feature that has sporadically been criticised in connection with the multiple-flow-direction algorithm (Tarboton, 1997). Furthermore, the model does not simulate sediment mobilisation which can enlarge the debris flow volume considerably. Model runs have shown, therefore, that the stored water volume of most alpine-sized glacier lakes is not sufficient for use in the model. The appropriate starting cell value is best evaluated during model 


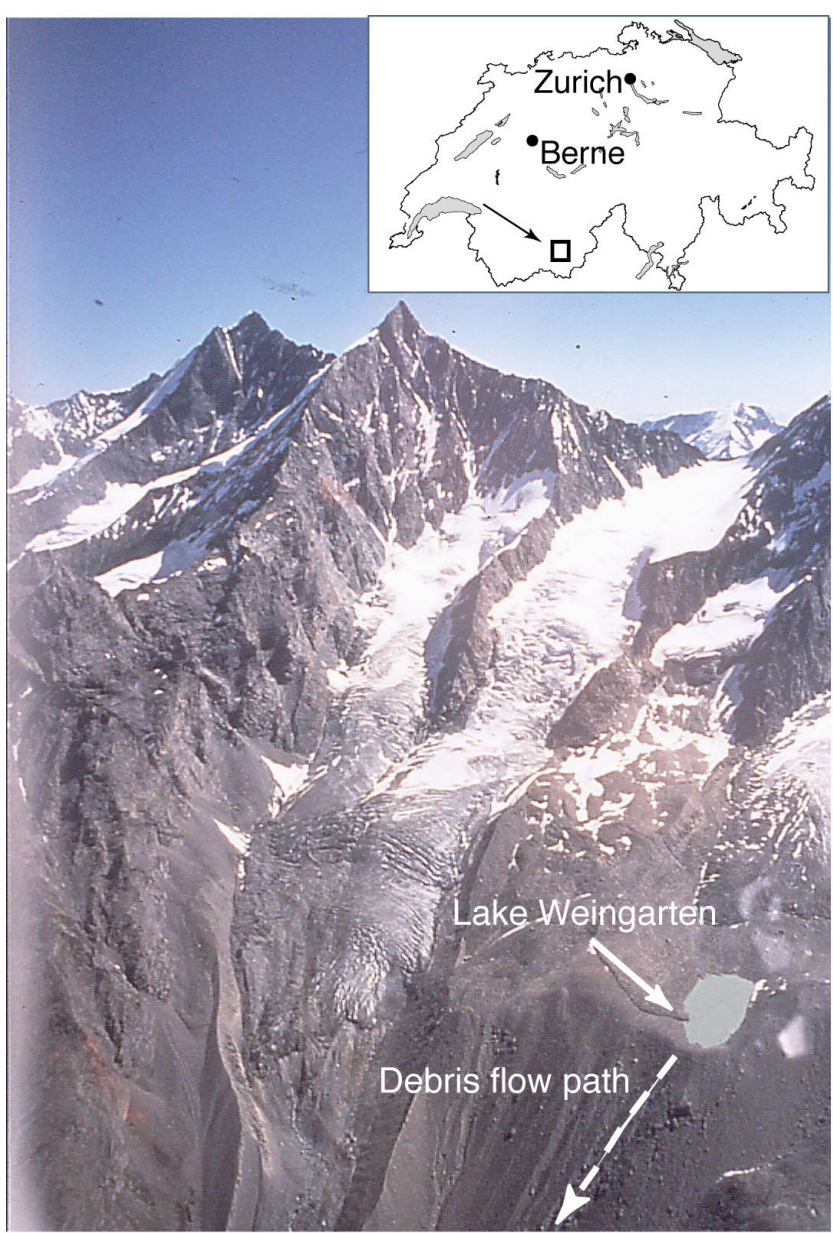

Fig. 2. Lake Weingarten with the large and steep moraine below, in the background the mountain peaks of Täschhorn and Dom (photo by W. Haeberli, July 1993).

runs. The amount of water draining through each cell such as calculated by the multiple-flow-direction algorithm is interpreted as a qualitative probability that this cell is affected by the debris flow. As with the MSF-model, the simulated debris flow is stopped where an average slope of $11^{\circ}$ is reached.

Problems with the model can arise from artificial dam structures present in the DEM causing the flow propagation to stop. Such dam artifacts have to be corrected in the DEM prior to model run. The MF-model, however, is much less sensitive to DEM-induced erroneous flow directions than the MSF-model. While in the case of the MSF-model one erroneous flow direction is potentially sufficient to significantly divert the flow, the MF-model will balance such errors. Flow and spread on convex terrain sections and debris fans is thus better simulated by the latter model.

\section{Model application}

\subsection{Täsch lake outburst/debris flow}

The village of Täsch is situated in the upper Matter valley close to Zermatt (Valais, Switzerland). Lake Weingarten
(3060 $\mathrm{m}$ a.s.l.) lies in front of Weingarten Glacier which flows down from the west face of Alphubel ( $4206 \mathrm{~m}$ a.s.1.). The lake is no longer in direct contact with the glacier and situated on a large Little Ice Age moraine deposit (Fig. 2): the moraine has a very steep, $700 \mathrm{~m}$ long slope of up to $36^{\circ}$ in loose sediment. Bedrock depth is in the range of 70 to $120 \mathrm{~m}$ (Zimmermann, pers. communication, 1999). Small incised channel structures are present at the outer side of the moraine. The section below the moraine down to Täschalp is characterized by slope angles of about $15^{\circ}$ to $20^{\circ}$. Several debris flows in the past from the same catchment (not related to lake drainage) have stopped at the debris fan of Täschalp. In the past decades, recreational structures and houses have been built on the fan and the trajectory is now confined to the northern edge of the fan by channelization. Below this section and over a short flatter part, the flow path proceeds into a steep gorge ending up directly at the upper edge of the village of Täsch. Like many alpine settlements, Täsch lies on the debris fan of the torrent from the tributary valley, thus enabling protection from floods in the main valley river. Protection against floods from the tributary torrent was achieved by the construction of an armoured channel across the village. This structure, however, was designed for pure-water floods with no significant sediment load.

On 25 June 2001, at around 22:00 LT, during a period without any significant precipitation, considerable parts of the village of Täsch were damaged or destroyed by a debris flow event. Thanks to an alarm given by persons observing the debris flow at Täschalp, 150 persons at Täsch could be evacuated just in time. Damages to buildings and other installations amounted to about 12 mill. EUR (Hegg et al., 2002).

During field inspections shortly after the event, we observed a shoreline 0.4 to $0.5 \mathrm{~m}$ above the water level of Lake Weingarten. The surface drainage channel of the lake was found intact. Based on a lake area of $16000 \mathrm{~m}^{2}$ (derived from a 1998 Landsat satellite image), we thus estimated the amount of overtopped water at 6000 to $8000 \mathrm{~m}^{3}$. Elevated air temperatures during the days prior to the outburst led to a high melt water input into the lake. The intact drainage channel and the presence of the shoreline let us suggest the following scenario: the lake was dammed probably by blockage of water by pieces of lake ice and snow deposits (the lake was partially covered by snow and ice at the time of the event). The resulting elevated water level could have caused higher hydraulic gradients in the moraine dam body and eventually piping processes. Water sources observed at the outer side of the moraine after the event could be an indication for piping and high water saturation in the moraine. Together with the (relatively moderate) flood after the rupture of the snow/ice blockage, such progressive groundwater flow probably caused erosion to start at the outer moraine slope. Retrogressive erosion at the outer side of the moraine stopped in short distance of $1-2 \mathrm{~m}$ to the lake. Thus, there was not a full erosive cut through the moraine. The draining water was, however, sufficient to initiate a debris flow.

In the uppermost section with abundant unconsolidated 


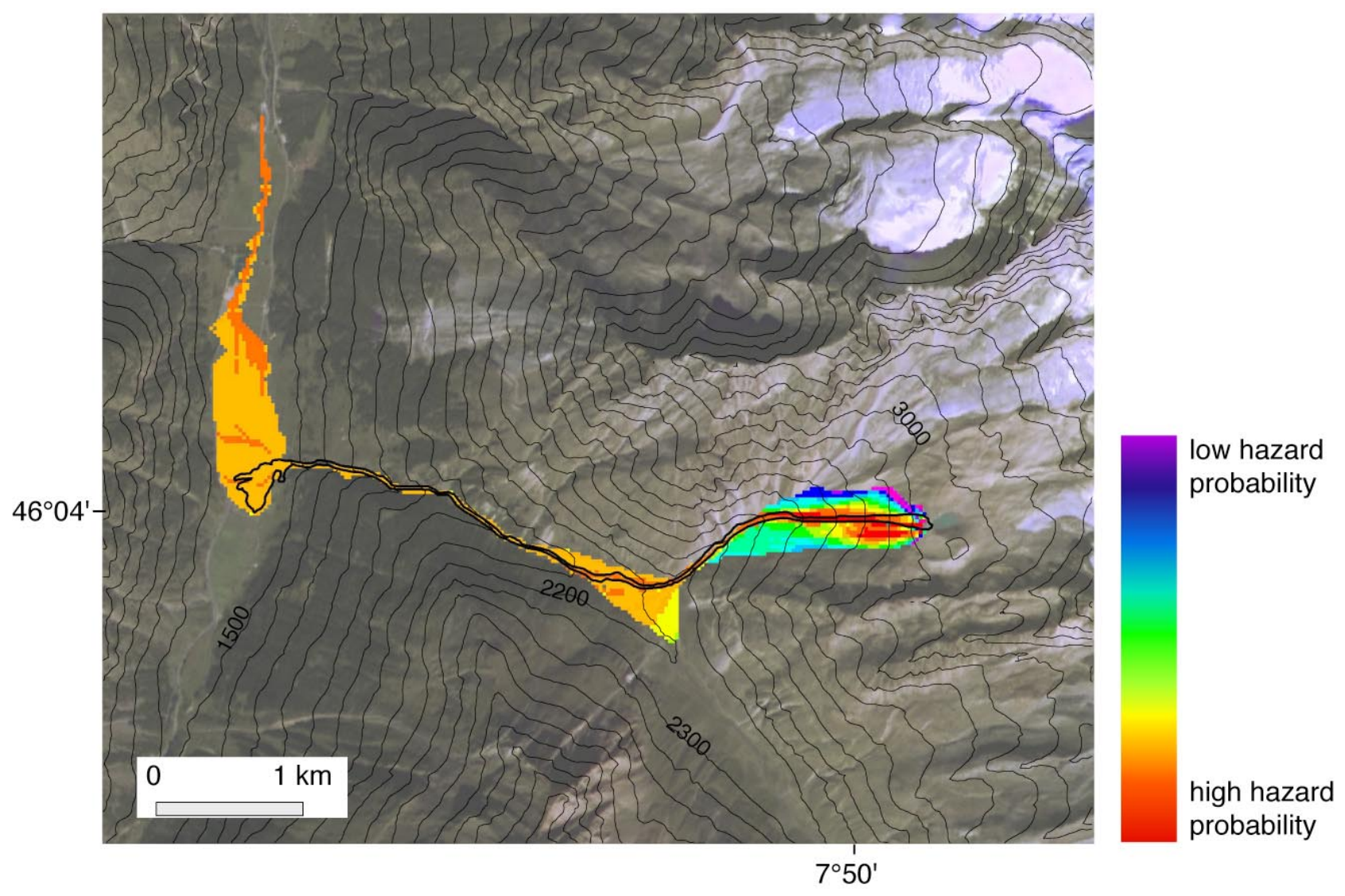

Fig. 3. Simulation of the Täsch debris flow by the MSF-model. Starting point is Lake Weingarten. Outlines of the 2001 debris flow are indicated by a black line. Areas to be affected by a debris flow of predictively high probability (in red) show good correspondence with the 2001 event (e.g. on the fan at Täsch). A fusion image of the 1998 Landsat-TM and the 1997 IRC-Pan scene is used as background (DHM25 (C) 2003 swisstopo, BA024722).

sediment, $25000-40000 \mathrm{~m}^{3}$ of debris were eroded with a maximum cross-sectional erosion of $30-50 \mathrm{~m}^{2}$. Right above the confluence with the torrent Rotbach below the moraine complex, field surveys showed increased erosion and sediment deposition. We therefore assume that the additional water input from the Rotbach caused a remobilization of sediment with strong erosion (P. Teysseire, pers. communication, 2002). Part of the entrained material was deposited at Täschalp where a bridge was destroyed. During the following passage through the gorge, sediment was probably neither deposited nor mobilized. At the fan apex, the debris flow front surged into the constructed channel. However, since the channel was not designed for such sediment loads, it immediately became obstructed and the debris flow spread out onto the fan causing the damages mentioned above. Our estimate of the total volume of debris deposited in Täsch was in the range of $20000-50000 \mathrm{~m}^{3}$.

\subsection{MSF-model}

The geo-referenced lake area, as the input for starting the flow process, was extracted from the 1998 Landsat satellite image. The only further input into the model was the
DHM25. For verification of the models, the debris flowaffected areas were digitized using field survey data, oblique aerial photography and the IRS-Pan satellite image.

The large flow spread of the model in the uppermost section below the lake stems from the convex morphology of the moraine complex favouring flow dispersion (Fig. 3). Existing flow channels in the moraine are too small (cross-sections of about $10-20 \mathrm{~m}^{2}$ ) to be adequately represented in the $25 \mathrm{~m}$ gridded DEM. Yet, the related probabilities show that the margins of the area covered by the model in this section are unlikely to be affected by the debris flow (blue to magenta colour $=$ low probability of being affected; Fig. 3). A comparable dispersion situation is found at Täschalp where the model pretends a spreading flow behaviour on the fan. In fact, this is a realistic modelling since historical debris flows (not related to lake outbursts) have often attenuated and spread on the fan. Nowadays, the channel is confined to the orographic right side because of channelization for flood protection of structures at Täschalp. The June 2001 event actually remained confined to the flow channel. In consideration of the small size of the event, the model nevertheless correctly indicates the possibility of the fan being affected by a high-magnitude event. The flow behaviour in the nar- 


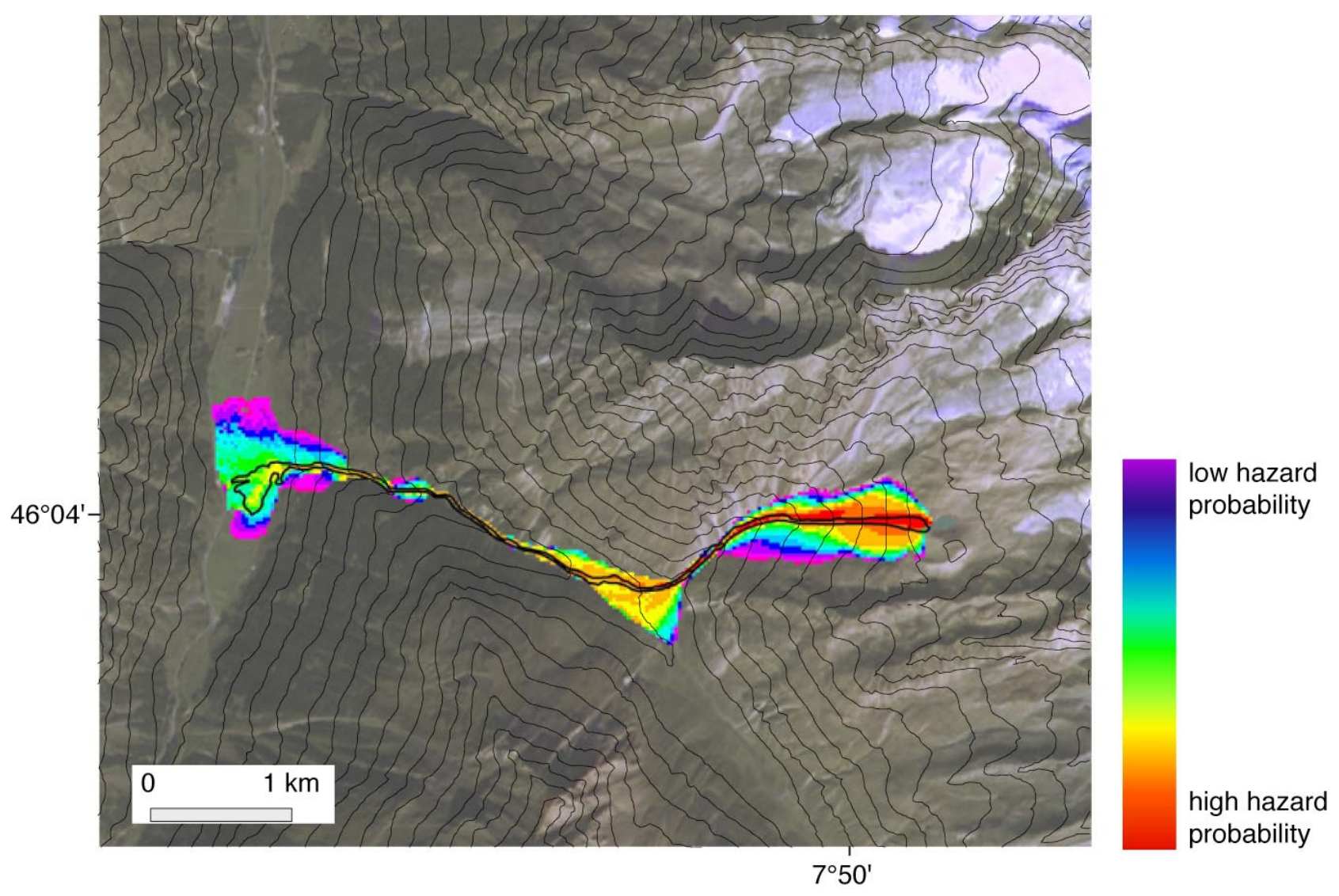

Fig. 4. Simulation of the Täsch debris flow by the MF-model. Starting point is Lake Weingarten. Outlines of the 2001 debris flow are indicated by a black line. Values corresponding to the full-spectrum scale are log-transformed. Due to convex terrain, strong flow diversion at the uppermost section can be recognized. Good correspondence with the 2001 event is found on the fan at Täsch.

row gorge below Täschalp is adequately represented by the model. In terms of model evaluation an essential section starts at the fan apex of Täsch. The model seems actually capable to simulate the spread of the debris flow on the fan (Fig. 3). However, the model accuracy must be limited since structures such as buildings, roads or bridges, which significantly influence the flow behaviour, are not represented in the DEM. Nevertheless, the location of areas with higher probability of debris flow impact is broadly confirmed by the 2001 event.

At the orographic right side, the model makes the debris flow deviate resulting in a relatively large area predictively affected (Fig. 3). At a first glimpse, this may seem an evident model error. Yet such points should be carefully checked since they may be an indication of critical locations in the field. Alternatively, the DEM might misrepresent the terrain characteristics. The maximum runout distance of the debris flow is set according to an average slope of $11^{\circ}$ (cf. Sect. 2.2). The simulated debris flow thus stops further downvalley from Täsch. In other words: our model predicts that Täsch is reached by the debris flow. This includes the possibility that the main river may be blocked by the debris flow with subsequent damming and possible sudden breach and flooding.
Though not the case for the 2001 event, such a process should be taken into account for larger debris flow events.

We are aware of the fact that the predicted runout beyond the confluence with the receiving main stream seems somewhat theoretical, and probably implies a different process (for instance, flooding after rupture of river blockage). However, not every case allows a clear differentiation of processes before and after the confluence. We therefore specifically want to preserve the 'safety' of the model which corresponds to a 'worst-case'. Stopping the model at the confluence, for instance, could prevent from crucial reflections regarding the impact of a potential event.

\subsection{MF-model}

As for the MSF-model, input for the MF-model is the DHM25 and the starting cell location. The value of the starting cells was iteratively found as $A=10^{9}$. In general, the MF-model yields a similar image as the MSF-model (Fig. 4). In the uppermost section of the moraine, the flow spread is too wide as compared to the 2001 event due to the same reasons as for the MSF-model (convex terrain and non-representation of small channels by the DEM). The ad- 
ditional water input at the confluence with the Rotbach was not integrated in the model. Basically, the model structure is sufficiently open to simulate similar sources of water inflow if such locations can be recognized in advance. It is expected that indications for remobilization processes could thus be gained. A strong dispersional component is found as well on Täschalp indicating its basic susceptibility in case of a highmagnitude event. The narrow gorge then keeps the simulated flow confined. At the main fan at Täsch, the flow dispersion resembles an evenly distributed pattern though two flow 'channels' (higher probability to be affected, orange to red color in Fig. 4) are discernible. These 'channels' actually coincide with the flow direction of the 2001 debris flow event (Fig. 4). Being aware of the predicted runout distance, we did not propagate the flow further downstream than the lower end of the fan at the confluence with the main valley river.

\section{Model sensitivity}

The previous sections have shown that the MSF-model is more robust and straightforward in propagating flow downwards and less user interaction is necessary. Complete integration of the modelling procedure within a GIS environment facilitates model handling and application. It has also become evident that DEM resolution, quality and accuracy are crucial for the model performance and result. Therefore, we tested the MSF-model for three different DEMs for a site where glacier lake outbursts have repeatedly taken place in the past. For all three DEM applications, the starting lake cells were extracted from the 1998 Landsat satellite image. For verification of the applied model, the debris flow-affected areas were digitized using an orthophoto of 1991 infrared aerial photography. Due to limited coverage of the orthophoto, the ground truth could not be assessed entirely down to the furthest runout point, i.e. assessment of the model performance on the fan had to be done using indications from other unpublished documents (e.g. photographs, personal experience).

\subsection{Gruben glacier floods and debris flows}

Five major glacier floods and related debris flows affected the village of Saas Balen, Saas Valley, Valais (1500 m a.s.l.), during the 19th and 20th centuries (Lichtenhahn, 1979). The source area of these events is a glacial cirque situated only $3 \mathrm{~km}$ from the village (Fig. 5). As a consequence of glacier recession and permafrost degradation, a number of lakes developed in the past decades around the tongue of Gruben Glacier which flows from the summit of the Fletschhorn ( $3993 \mathrm{~m}$ a.s.1.) down to the bottom of the cirque (around $2800 \mathrm{~m}$ a.s.1.). For historical reasons the different lakes are numbered from 1 to 6 . The most recent glacier floods occurred in 1968 and 1970 and involved the ice-marginal Lake No. 3 and the proglacial Lake No. 1. Both events were triggered by a catastrophic drainage of Lake No. 3 by progressive enlargement of subglacial channels (Haeberli et al.,

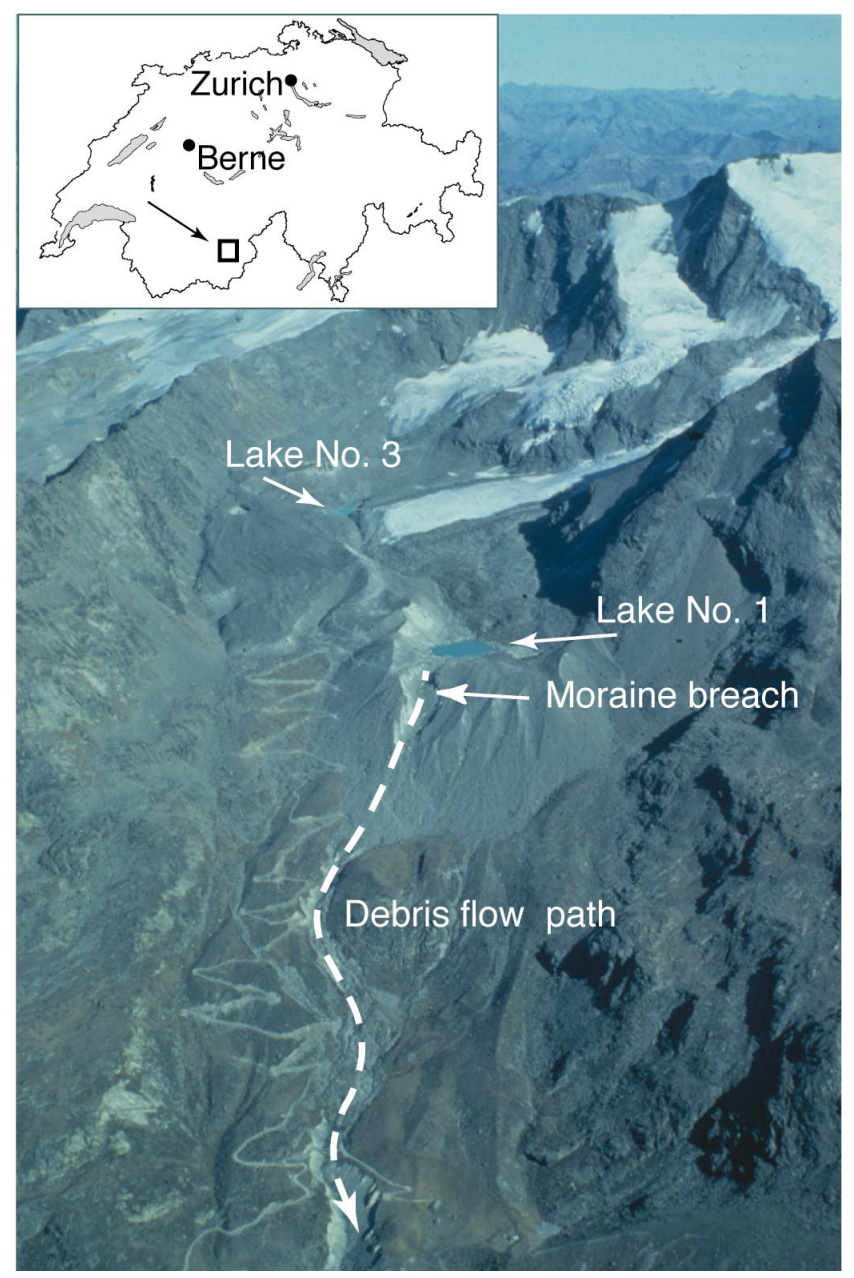

Fig. 5. View on the Gruben cirque showing proglacial lake No. 1 and ice-marginal lake No. 3. The breach in the moraine can be recognized as well as erosional and depositional traces of the glacier floods (photo by W. Schmid).

2001). In 1968 , the outburst volume of $170000 \mathrm{~m}^{3}$ provoked formation of a breach and strong erosion of about $400000 \mathrm{~m}^{3}$ of debris within the Holocene morainic material which dammed Lake No. 1. In case of the 1970 event, about $100000-150000 \mathrm{~m}^{3}$ were eroded similarly (Haeberli et al., 2001). The section below the moraine bastion is characterized by varying erosion and deposition of debris flows. A narrow and steep gorge then leads directly to the debris fan upon which the village of Saas Balen is built. The event of 1968 caused especially heavy damage to the village. After 1970, mitigation measures were begun. At Lake No. 1 an artificial dam was constructed to prohibit retrogressive erosion in case of unpredictable floods from upstream lakes or subglacial reservoirs (Röthlisberger, 1981).

\subsection{DHM25}

The results of the application of the MSF-model with the DHM25, Level 2, in comparison with the ground truth show 


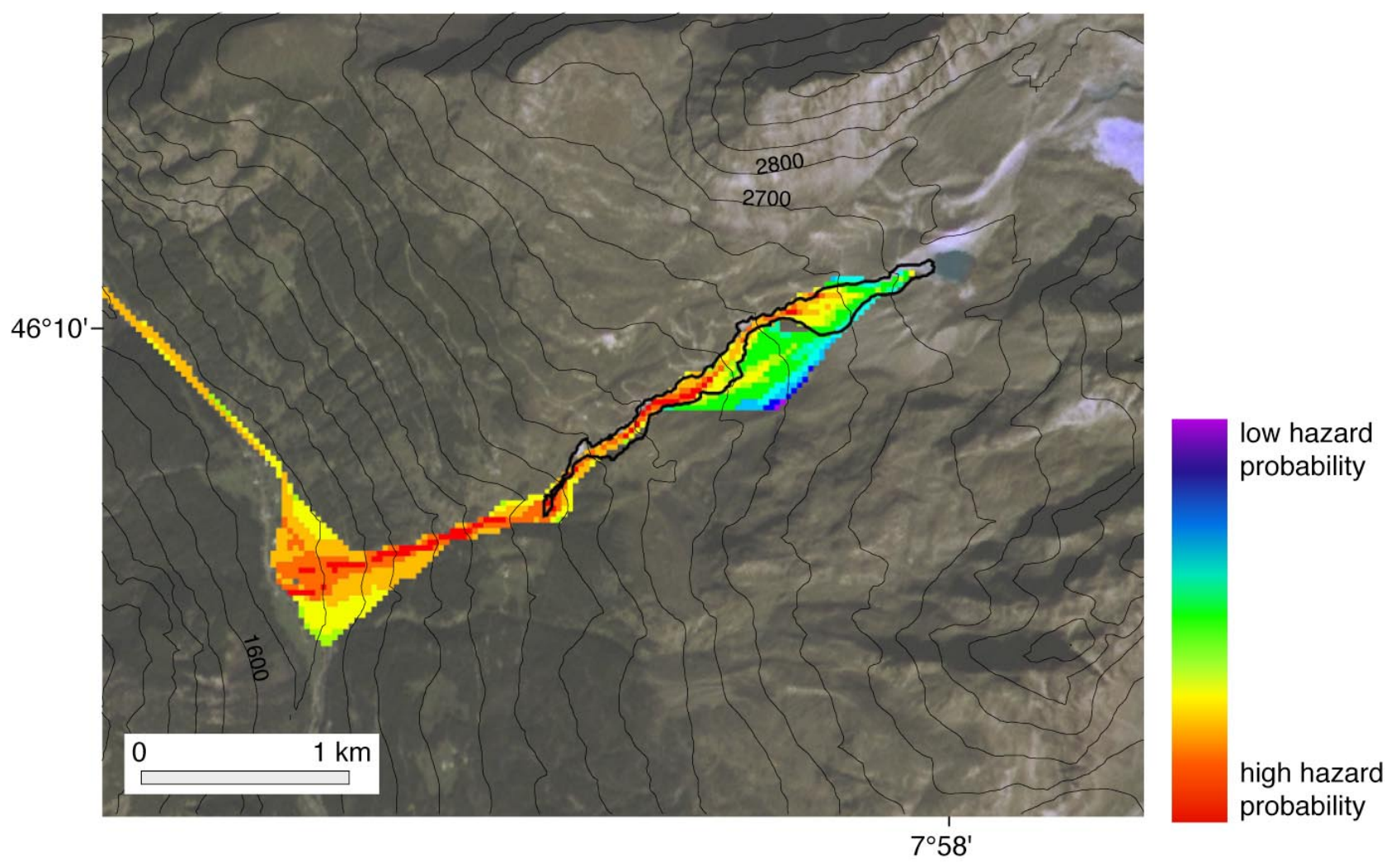

Fig. 6. Model run of the MSF-algorithm with the DHM25. Starting point is Gruben Lake No. 1. Outlines of the 1968/1970 debris flow/lake outbursts are indicated by a black line. In the area with ground truth, correspondence between model and real event is very reasonable. A fusion image of the 1998 Landsat-TM and the 1997 IRC-Pan scene is used as background (DHM25 (C) 2003 swisstopo, BA024722).

the following (Fig. 6): the general flow path is well represented. Immediately after the moraine breach, the 1970 debris flow had a stronger spread component than the more probable values of the model indicate. Then the model shows two different flow paths where the 1970 debris flow remained confined to the orographic right side. The right flow path has higher probabilities in the model but the left path can be considered as an alternative flow path. Although here the model seems incorrect compared to the ground truth, it probably indicates a realistic potential for a debris flow to deviate to the left.

Some more detailed geometric features of the debris flow indicating strong lateral erosion are not adequately represented by the model. This is because neither processes of lateral nor of vertical erosion are included in the model. On the fan down in Saas Balen, the model spreading behaviour is very reasonable, and the corresponding probabilities are capable to give a correct estimate of the most susceptible areas (Fig. 6). At the fan apex, the model runs too early towards a lateral spread. Missing DEM accuracy or resolution may be the reason. The furthest point of runout is defined according to an average slope of $11^{\circ}$. Similarly to the Täsch case, the simulated debris flow stops further downvalley from the village. Possibility of blockage of the main river in Saas Balen should thus be considered, and, in fact, has happened in case of the 1968 event including subsequent flooding. As outlined for Täsch, arbitrary stopping of the model at the confluence would eliminate an important tool of the inherent 'safety' of the assessment.

\subsection{Satellite image-derived DEM (ASTER)}

The motivation of the application of the ASTER DEM is its potential use in any high-mountain region worldwide according to the global coverage of ASTER data. The results of the application of the MSF-model (Fig. 7) indicate that the degree of terrain detail in the ASTER DEM is significantly less than in the DHM25, though both DEMs have the same ground resolution (i.e. $25 \mathrm{~m}$ ). In general, the ASTER model shows a stronger lateral spread. Directly below Lake Gruben No. 1, the model leaves the 1970 debris flow path and begins to spread broadly. The likely reason is that the ASTERderived DEM is not sufficiently accurate in representing terrain details (e.g. incised flow channels) and the general convex terrain form provokes the lateral spread. However, if we focus on the probabilities, the most likely flow path and area affected are quite well assessed (Fig. 7).

The small and steep gorge following the upper and middle section of erosion and deposition is not adequately represented in the ASTER DEM. The same is true for the debris fan at Saas Balen. Obviously, the ASTER-derived DEM 


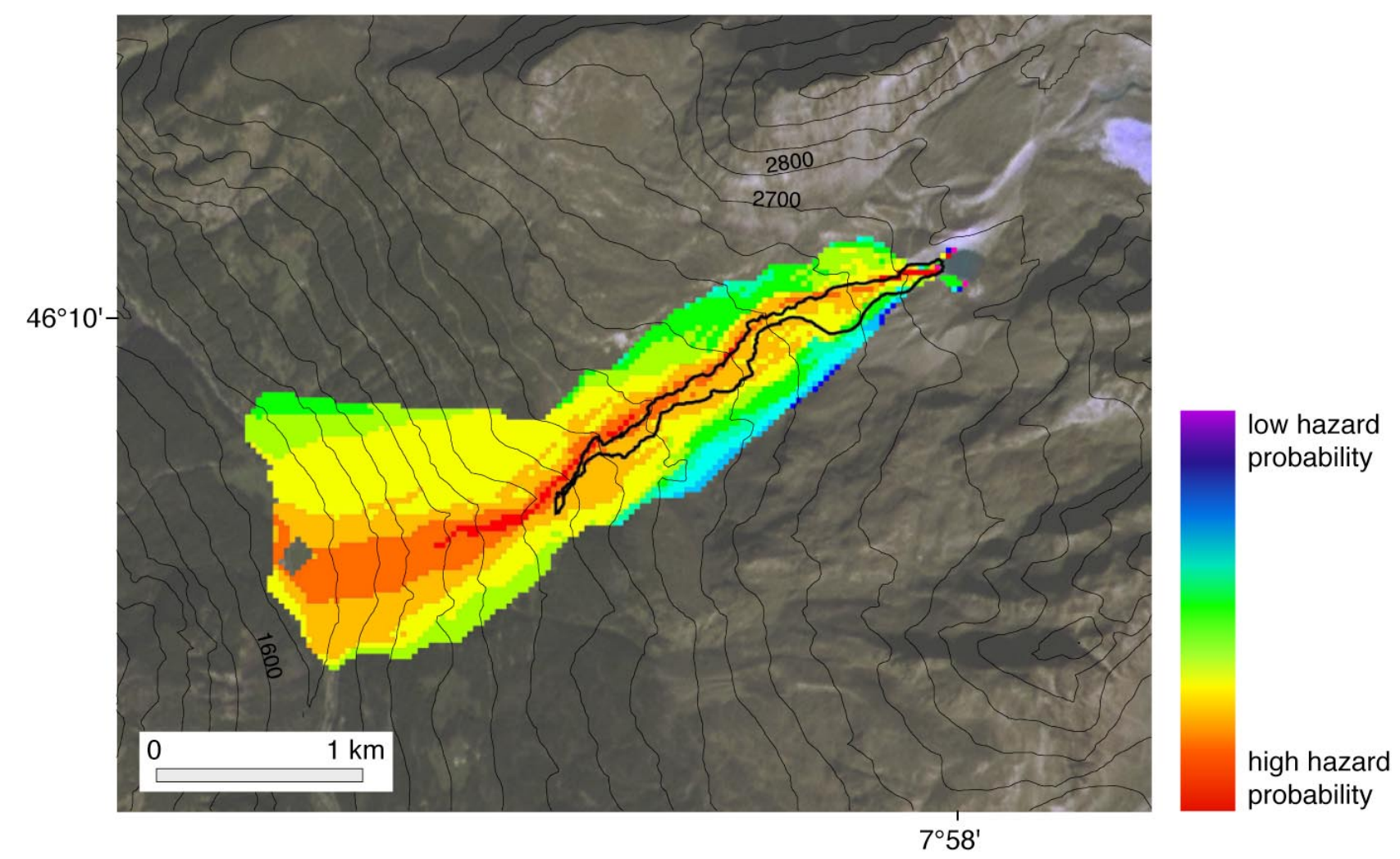

Fig. 7. Model run of the MSF-algorithm with the ASTER-derived DEM. Starting point is Gruben Lake No. 1. Outlines of the 1968/1970 debris flow/lake outbursts are indicated by a black line. Though the flow diversion in the model is strong, the most probably affected areas correspond fairly well to the real event.

does not allow for a sufficient representation of alpine-sized fan structures to simulate the debris flow behaviour on the fan by the present model. Reduced DEM quality can also be recognized where the model predicts a slight run-up on the opposite slope since the model algorithm does not allow run-up on a slope. Nevertheless, the ASTER DEM can be a low-cost alternative (ASTER data can be purchased at a minimum cost) for some rough regional assessment, maybe less useful in countries like Switzerland with excellent data availability but much more so in remote and poorly documented high mountain regions of the world (Huggel et al., 2003; Kääb et al., 2003).

\subsection{Aerial photograph-derived DEM}

A third model run was performed with the high-resolution DEM derived from aerial photography. The objective was to investigate to which extent the model can be improved using a highly detailed DEM.

Results of the model application (Fig. 8) show that there is very limited flow spread in the breach below Gruben Lake No. 1 pointing to an adequate representation of the breach morphology by the DEM. On the other hand, it confirms that the model does not allow for simulation of erosion and breach forming processes. Below the moraine there is good correspondence between the model and the ground truth. As with the DHM25, a second left-turning flow path of slightly reduced probability is predicted. Hence, this high-quality DEM confirms the potential for a debris flow to deviate at this point though the 1970 event remained confined to the right side. Such information is of particular interest for a predictive hazard assessment. In contrast to the model runs based on the DHM25 and the ASTER DEM, the present simulation indicates a further flow deviation at the lower section (Fig. 8). Due to the limited data coverage, it is not possible to investigate this additional flow path and possible consequences of the deviation. In general, the model follows precisely the 1970 event (highest probabilities). However, it opens the view on additional potentially-affected areas which are important to be considered in any hazard assessment.

In order to get control over the quantitative differences of the DEMs the model is based upon, an arithmetic comparison of the DEMs used was performed. Taking the most accurate DEM (aero-photogrammetry-based) as a reference, we calculated the positive and negative differences to the DHM25 and the ASTER DEM (Fig. 9). For the DHM25, highest differences were found around mountain peaks with maximum deviations of $\pm 35 \mathrm{~m}$. In the area relevant for the MSF-model, DEM deviations were $\pm 10 \mathrm{~m}$ at a maximum. The ASTER DEM revealed maximum errors between $-85 \mathrm{~m}$ and $+75 \mathrm{~m}$ for isolated mountain peaks and up to $\pm 25 \mathrm{~m}$ in the area of the debris flow. 


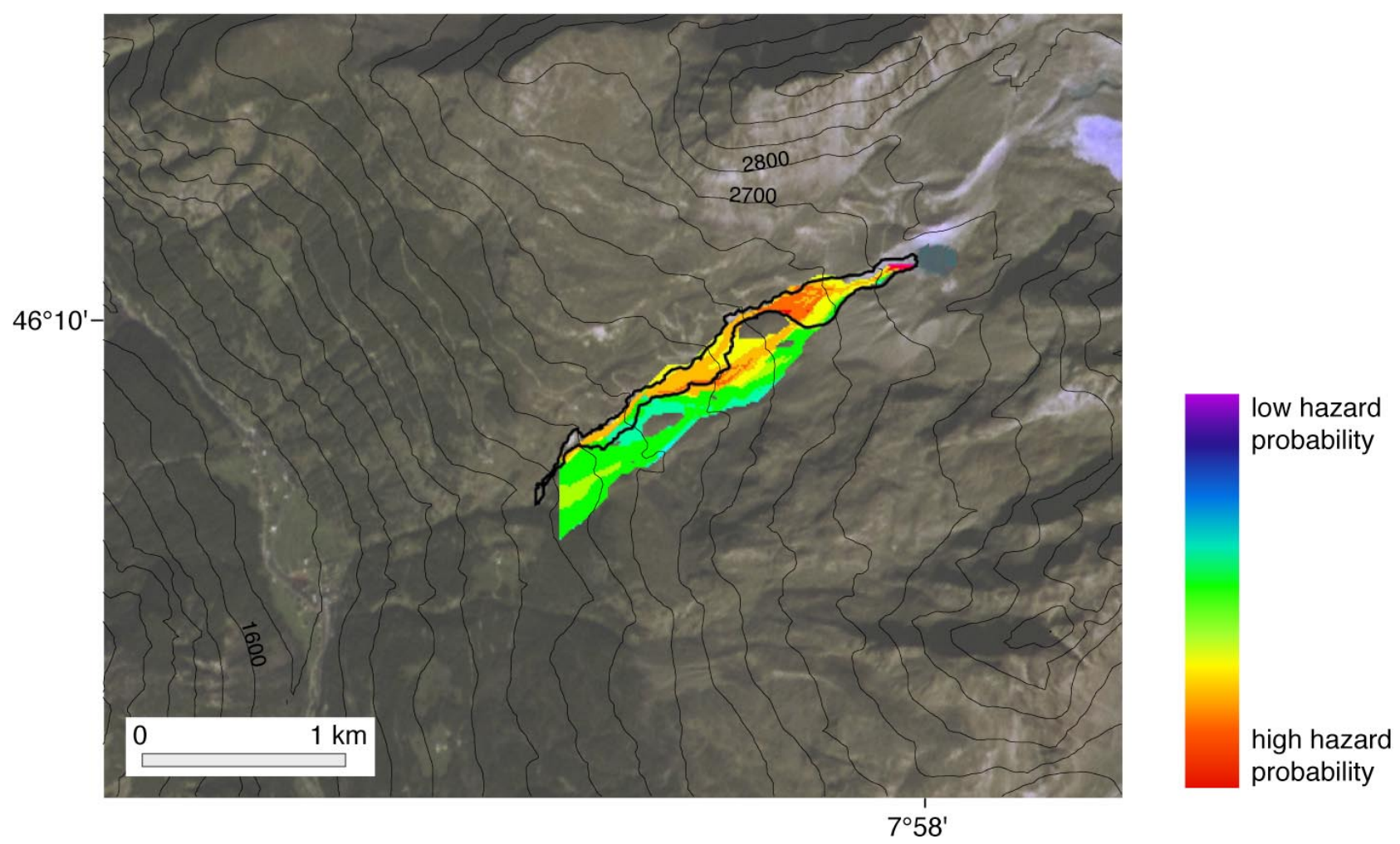

Fig. 8. Model run of the MSF-algorithm with the aero-photogrammetrically-derived DEM. Starting point is Gruben Lake No. 1. Outlines of the 1968/1970 debris flow/lake outbursts are indicated by a black line. Due to limited coverage of the aerial photographs, the DEM (and hence the model) does not include the lower part of the debris flow including Saas Balen.

\section{Regional application}

Although we tested and verified the lake outburst models on two single events, we are not aiming at applications for detailed predictions of local debris flow-affected zones. The approach chosen rather justifies and favours a broader regional application where indications of potential hazards can be derived (in the sense of a first-order assessment). Remote sensing data is particularly capable to provide area-wide and current information of highly dynamic high mountain - and especially glacier-lake - environments. We used the 1998 Landsat-TM scene of the Matter and Saas valley region for detection of potentially hazardous lakes with an approach according to Huggel et al. (2002). An index of different spectral TM channels is thereby used to detect the lakes. A set of lake and terrain parameters allows then to extract potentially hazardous lakes. For more detail on the method, see Huggel et al. (2002). The number of lakes selected includes some ones that already produced an outburst flood such as Lake Weingarten and Lake Gruben (cf. Sect. 3.1 and 4.1, both now with mitigation measures concluded), or Lake Rottal (Haeberli, 1983). A special case represents Lake Sirwolte which experienced a catastrophic lake drainage in 1993 and no longer exists since then (Huggel et al., 2002). Nevertheless, we here included it for visualisation of the model performance. Since the lakes were assessed based on a first-order assessment, there is need for more detailed investigations for precise evidence on the hazard potential.

For its robustness and complete implementation in a GIS, the MSF-model is preferred for a regional application. The remote sensing data-derived lake information provides direct input to the GIS model and represents the starting cell location for the simulated lake outbursts. The model is run with the DHM25. Figure 10 shows the result of the model run. It is evident that based on a 'worst-case' approach all of the lake outbursts simulated reach the valley bottom and thus potentially installations. In most cases, the areas of the valley bottom show a moderate to considerable degree of hazard probability. A corresponding risk assessment is beyond the scope of this study. The theoretical runout predicted by the model is in all cases set according to an average slope of $11^{\circ}$ irrespective of the individual geomorphological conditions. On a regional scale level, we consider the degree of 'safety' thus preserved as of highest priority. Subsequent studies may then confine the runout and differentiate the processes before and after the confluence with the receiving stream.

\section{Discussion}

Hazard assessments dealing with glacier lake outbursts are facing a highly dynamic environment susceptible to climatic 

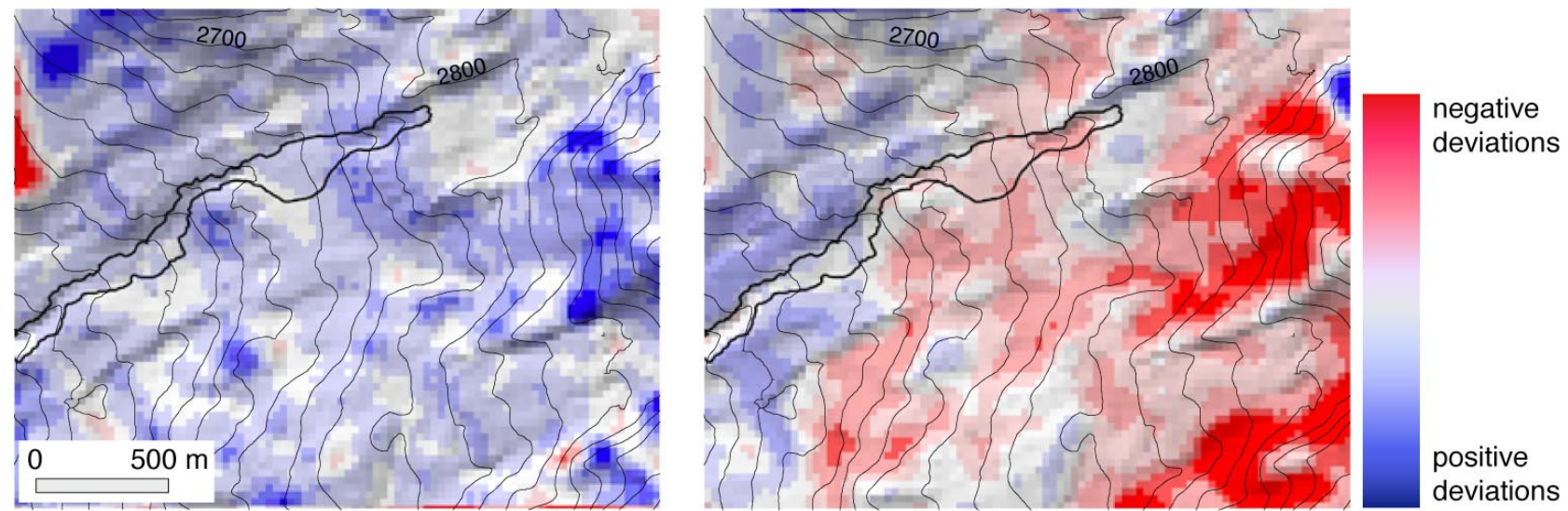

Fig. 9. Elevation differences calculated between the aero-photogrammetrically-derived DEM and the DHM25 (left) and the ASTER-derived DEM (right), respectively. For the DHM25, the standard deviation is $4.7 \mathrm{~m}$, for the ASTER-DEM the standard deviation is $18.4 \mathrm{~m}$. In the debris-flow zone, maximum deviations are not larger than $10 \mathrm{~m}$ and $25 \mathrm{~m}$, respectively.

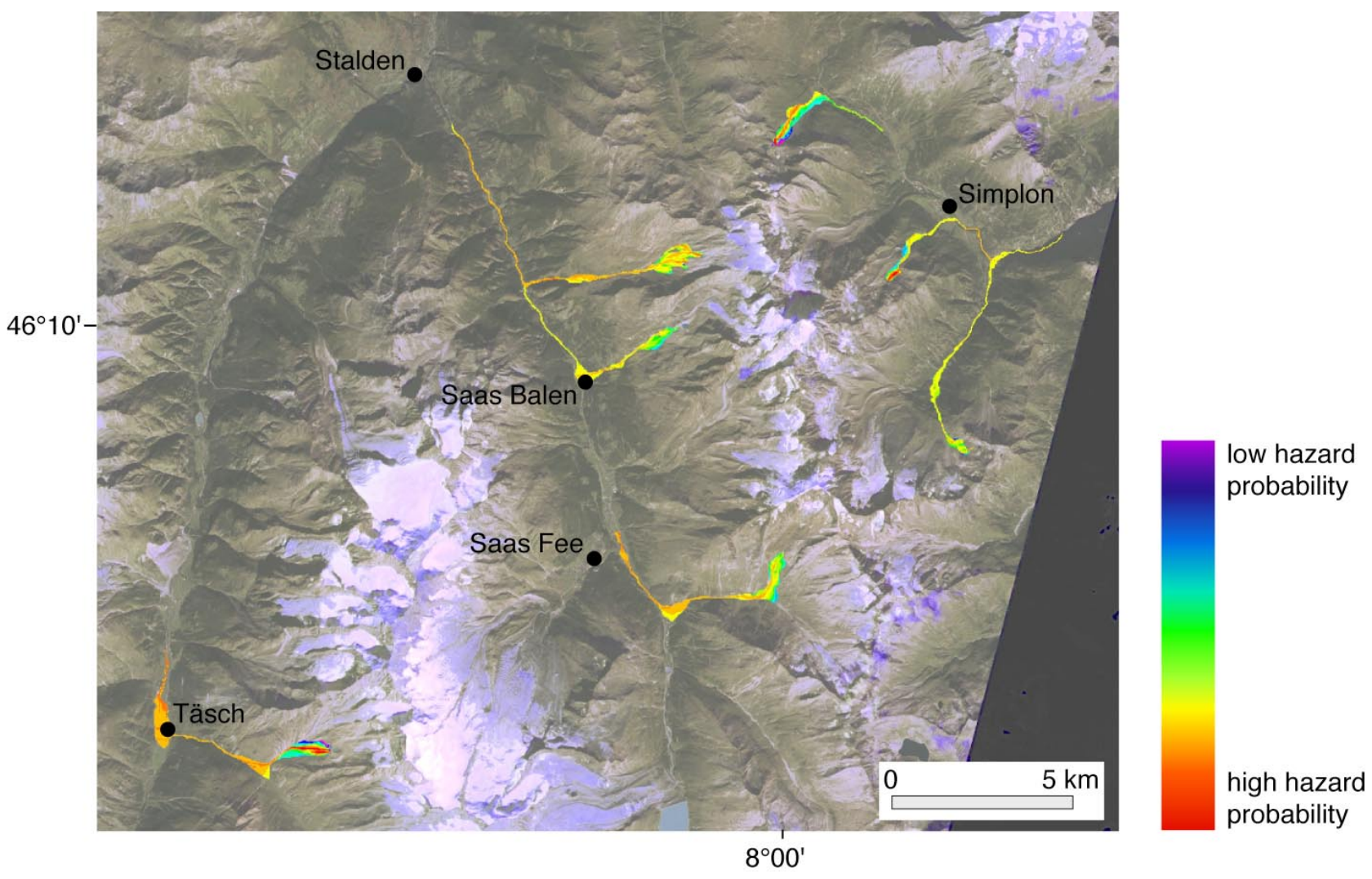

Fig. 10. Regional-scale application of the MSF-model in the southern Swiss Alps (Matter- and Saas valley, Simplon region). The model is projected on a fusion image of the 1998 Landsat-TM and the 1997 IRC-Pan scene. All simulated lake outbursts reach the bottom of the main valley.

and other environmental changes. Assessments based on current information is crucial in this context. However, in high mountain regions, regular data acquisition is often constricted to remote methods due to access limitations. In our combined approach, we therefore rely on remote-sensing data for detecting and selecting potentially hazardous lakes. The models subsequently applied can be seen in the frame of first-order hazard assessments using a 'worst-case' approach. They allow for the prediction of flow paths and the range of areas affected including the maximum runout. Both models 
strongly rely on digital terrain information and do not take into account geotechnical or geological conditions in the flow channel, e.g. exposed bedrock or unconsolidated sediment. As a consequence, the models do not give directly any information on the expected debris flow volume, amount of sediment eroded and deposited, nor on the maximum discharge. Such estimates can subsequently be made, for instance, using empirically-derived relations (Hungr et al., 1984; Haeberli et al., 1989; Haeberli et al., 1991; Rickenmann and Zimmermann, 1993; Rickenmann, 1999). Analysis of highresolution multispectral remote-sensing data and aerial photography can support such assessments (Kääb, 2000, 2002; Huggel et al., 2002). Qualitatively, however, the model result can indicate areas of dominant sediment erosion or deposition corresponding to the sections of varying flow spread.

An overall model evaluation indicates that the MSF-model is more robust and straightforward in propagating flow downwards, and less user interaction is necessary. Complete modelling procedure within a GIS environment facilitates model handling and application. The MF-model, on the other hand, is better capable to model flow propagation on the fan and less sensitive to DEM-induced flow direction errors. In confined channel sections artificial dams in the DEM can be a problem for the multiple-flow-direction approach. The structure of the MF-model tends to be more adaptable to user modifications. For instance, flow divergence can be confined by modifying Eq. (2). For this reason, Holmgren (1994) has suggested to introduce a variable exponent for $\tan \beta$ thus governing the amount of water that flows across a particular flow direction. Modification of the MSF-model is possible by adapting the flow diversion resistance in the pathdistance function $P_{a}(i)$ in Eq. (1), or by considering other weighting schemes.

The use and availability of DEMs is a crucial factor in applying the models presented here. The evaluation of different types of DEMs for application with the MSF-model yielded the following: The use of a publicly available $25 \mathrm{~m}$ gridded DEM in Switzerland (DHM25, Level 2) is probably best qualified for first-order assessments of glacier-lake outburst hazards in alpine regions. Model runs showed that the accuracy is sufficient for the scope of such assessments. The robustness of the MSF-model allows for small errors in the terrain representation, or makes them evident. Also, the flow spread on the debris fan could be reasonably simulated with the DHM25.

In complex alpine terrain with characteristic close distance of installations to hazard sources, the ASTER-derived DEM can hardly satisfy the need for assessments of hazards from glacier lake outbursts. The fundamental importance of ASTER-derived DEMs becomes evident in remote highmountain regions where access is difficult or prohibitive and basic ground-based data is lacking (e.g. in the Himalayas, Tien-Shan, Andes; Reynolds, 1992; Huggel et al., 2003; Kääb et al., 2003). Model evaluation with DEMs of coarser resolution than the ASTER DEM could be an option, e.g. for possible use in less developed countries, but was not considered necessary because ASTER data has a global coverage and is of no or very low acquisition cost. Related DEMs can thus be generated for any mountain region worldwide given the availability of cloud-free scenes.

Photogrammetrically-based techniques have the potential to generate the most accurate DEMs. We used such a DEM with a high degree of morphological detail and $10 \mathrm{~m}$ ground resolution to test the model's performance in combination with a high-quality DEM. As far as the reduced coverage of the $10 \mathrm{~m}$ DEM allows the conclusion, there are no major changes in comparison to the DHM25 application (except for a stronger flow spread in the middle section). Possible reasons are the high quality of the DHM25, and/or a relative insensitivity of the model to small terrain changes. Limitations from the use of photogrammetrically-derived DEMs stem from the high financial and work expenses and, hence, make them rather unsuitable for regional developments.

In all DEMs used here, structures such as bridges, armoured channels or buildings are not represented. Nevertheless, they can significantly influence the debris flow behaviour, especially on the fan. The presented models, therefore, have limitations in providing details on flow characteristics in the runout zone on the fan. In any case, evidence of impact on specific installations is out of the scope of this study. For future research however, the model may be tested in conjunction with very high-resolution DEMs (2$5 \mathrm{~m}$ ground resolution). Such DEMs can be generated from airborne laser-scanning data or aerial photography at large scale (larger than 1:10000) (Baltsavias et al., 2001) and allow the integration of built structures. In DEMs of coarser resolution, structures obtained from field investigations or large-scale maps can be incorporated as breaklines. In addition, planned mitigation measures (e.g. dams) can be integrated in the DEM by sophisticated tools for artificial landscape shaping.

In general, a first-order assessment recognizing a certain hazard for humans and human installations forms the starting point for more detailed investigations. These may provide more information on the expected lake breaching mechanism and the resulting flow hydrograph (Walder and O'Connor, 1997), debris flow volume (Iverson et al., 1998; Rickenmann, 1999), sediment entrainment (Zimmermann and Lehmann, 1999; O'Connor et al., 2001), or structures potentially affected (Nakagawa and Takahashi, 1997). Furthermore, 2-D and 3-D debris flow models that are able to yield more detailed information on the flow behaviour have been presented (Hirano et al., 1997; Gamma, 2000). For predictive use, some of these models have limitations stemming from the necessary high-resolution DEM (usually $10 \mathrm{~m}$ or finer gridded resolution) and a number of parameters that are difficult to assess in advance, and, hence, may lower the reliability of the model.

These limitations become a serious obstacle when applications in remote high-mountain regions are required (Kääb et al., 2003). For instance, the Himalayas and the Andes have repeatedly been the focus of major glacier lake outburst disasters but usually lack even basic data such as a DEM (Richardson and Reynolds, 2000). In such regions, a robust 
model which can be combined with remote sensing data is of particular importance. Application of similar models such as presented here in the Peruvian Andes has shown the basic validity and benefit (Huggel et al., 2003).

\section{Conclusion}

This paper shows how remote sensing and GIS technology can be integrated for hazard assessments of glacier lake outbursts. Two topography-based models with a single- and a multiple-flow-direction approach are presented. The model applying a modified single-flow-direction algorithm proved to be more suitable for the chosen approach of regional-scale first-order assessments. The evaluation of different DEMs has proved to be a crucial factor in model application. The aero-photogrammetrically-generated DEM with the highest degree of terrain detail may only be applicable for certain local-scale studies. The $25 \mathrm{~m}$-gridded DEM (DHM25) is suited for regional hazard assessments in the Swiss Alps, due to its high quality. The ASTER-derived DEM is suggested for model application in remote and poorly documented high-mountain regions worldwide. Future applications in such regions may also benefit from data from the Shuttle Radar Topography Mission (SRTM) and generation of related DEMs which may be comparable or superior to ASTER-DEMs.

Acknowledgements. This study was made possible thanks to the Swiss National Science Foundation, as part of the NF21-59045.99 project. The paper has much benefited from discussions with, and information, on the Täsch debris flow by Philippe Teysseire and Markus Zimmermann. Free availability of the multiple-flowdirection program code by Keith Beven is acknowledged. Thanks are also due to Andreas Bachmann for providing program codes, to Frank Paul and Stephan Gruber for important suggestions and to Sonja Oswald for field assistance. Reviews by Bijan Khazai, Nicholas Sitar and an anonymous reviewer have improved the paper.

\section{References}

Ames, A.: A documentation of glacier tongue variations and lake development in the Cordillera Blanca, Peru. Z. Gletscherkd. Glazialgeol., 34, 1-36, 1998.

Baltsavias, E. P., Favey, E., Bauder, A., Boesch, H., and Pateraki, M.: Digital surface modelling by airborne laser scanning and digital photogrammetry for glacier monitoring, Photogramm. Rec., 17 (98), 243-273, 2001.

Beven, K.: TOPMODEL Fortran source code, Lancaster University, Lancaster, 1995.

Beven, K. J.: Topmodel: a critique, In: Distributed hydrological modelling, applications of the TOPMODEL concept, edited by Beven, K. J., Wiley, Chichester 1-17, 1997.

Beven, K. J. and Kirkby, M. J.: A physically-based variable contributing area model of basin hydrology, Hydrological Science Bulletin, 24, 43-69, 1979.

Bundesamt für Landestopographie: DHM25. Das digitale Höhenmodell der Schweiz, Level 2, Bundesamt für Landestopographie, Wabern, 2001.
Campbell, R. H. and Chirico, P.: Geographic Information System (GIS) Procedure for Preliminary Delineation of Debris-Flow Hazard Areas From a Digital Terrain Model, Madison County, Virginia, U.S. Geological Survey Open-File Report 99-336A, U.S. Geological Survey, Denver, 1999.

Carrara, A., Cardinali, M., Guzzetti, F., and Reichenbach, P.: GIS technology in mapping landslide hazard, In: Geographical Information Systems in Assessing Natural Hazards, edited by Carrara, A. and Guzzetti, F., Kluwer Academic Publishers, Dordrecht, Netherlands, 135-175, 1995.

Chiarle, M. and Mortara, G.: Esempi di rimodellamento di apparati morenici nell' arco alpino italiano, Suppl. Geogr. Fis. Dinam. Quat., V, 41-54, 2001.

Clague, J. L. and Evans, S. G.: Formation and failure of natural dams in the Canadian Cordillera, Geological Survey of Canada Bulletin, 464, 1994.

Clague, J. J. and Evans, S. G.: A review of catastrophic drainage of moraine-dammed lakes in British Columbia. Quat. Sci. Rev., 19, 1763-1783, 2000.

Costa-Cabral, M. and Burges, S. J.: Digital elevation model networks (DEMON): A model of flow over hillslopes for computation of contributing and dispersal areas. Water Resour. Res., 30 (6), 1681-1692, 1994.

Desmet, P. J. J. and Govers, G.: Comparison of routing algorithms for digital elevation models and their implications for predicting ephemeral gullies, Int. J. Geogr. Inf. Sci.,10 (3), 311-331, 1996.

Dorren, L. K. A.: A review of rockfall mechanics and modelling approaches, Progress in Physical Geography, 27 (1), 69-87, 2003.

ESRI: ArcInfo 8.1, Environmental Systems Research Institute Inc. (online) URL: http:// www.esri.com, 2002.

Evans, S. G. and Clague, J. J.: Recent climatic change and catastrophic geomorphic processes in moutnain environments, Geomorphology, 10, 107-128, 1994.

Freeman, T. G.: Calculating catchment area with divergent flow based on a regular grid, Comput. Geosci, 17, 709-717, 1991.

Fuchs, S., Keiler, M., and Zischg, A.: Risikoanalyse Oberes Suldental, Konzepte und Methoden zur Erstellung eines Naturgefahrenhinweis-Informationssystem, Institut für Geographie der Universität Innsbruck, Innsbruck, 2001.

Gamma, P.: dfwalk - Ein Murgang-Simulationsprogramm zur Gefahrenzonierung, Geographisches Institut der Universität Bern, Bern, 2000.

Garbrecht, J. and Martz, L. W.: The assignment of drainage direction over flat surfaces in raster digital elevation models, Journal of Hydrology, 193, 204-213, 1997.

Haeberli, W.: Frequency and characteristics of glacier floods in the Swiss Alps, Ann. Glaciol., 4, 85-90, 1983.

Haeberli, W. and Beniston, M.: Climate change and its impacts on glaciers and permafrost in the Alps, Ambio, 27 (4), 258-265, 1998.

Haeberli, W., Alean, J.-C., Müller, P., and Funk, M.: Assessing risks from glacier hazards in high mountain regions: some experencies in the Swiss Alps, Ann. Glaciol., 13, 77- 101, 1989.

Haeberli, W., Kääb, A., Vonder Mühll, D., and Teysseire, P.: Prevention of outburst floods from periglacial lakes at Gruben Glacier, Valais, Swiss Alps, J. Glaciol., 47 (156), 111-122, 2001.

Haeberli, W., Rickenmann, D., and Zimmermann, M.: Murgänge. In: Ursachenanalyse der Hochwasser 1987, Ergebnisse der Untersuchungen, Mitteilung des Bundesamtes für Wasserwitschaft, 4, Bern, 1991.

Hanisch, J., Koirala, A., and Grabs, W. E.: Ausbrüche von Gletscherseen in Nepal und ihre mögliche Verhinderung, Zeitschrift für 
angewandte Geologie, 42, 8-13, 1996.

Heinimann, H. R., Hollenstein, K., Kienholz, H., Krummenacher, B., and Mani, P.: Methoden zur Analyse und Bewertung von Naturgefahren, Bundesamt für Umwelt, Wald und Landschaft (BUWAL), (ed.), Bern, 1998.

Hegg, C., Badoux, A., Frick, A., and Schmid, F.: Unwetterschäden in der Schweiz im Jahre 2001, Wasser, Energie, Luft, 94 (3/4), 99-105, 2002.

Hirano, M., Harada, T., Banihabib, M. E., and Kawahara, K.: Estimation of hazard area due to debris flow. In: Debris-flow hazard mitigation: mechanics, prediction, and assessment; edited by Chen, C.-L., Proc. 1st international conference, San Francisco, California, August 7-9, 1997, American Society of Civil Engineers, 697-706, 1997.

Holmgren, P.: Multiple flow direction algorithms for runoff modelling in grid-based elevation models: an empiric evaluation, Hydrol. Process., 8, 327-334, 1994.

Huggel, C., Haeberli, W., Kääb, A., Hoelzle, M., Ayros, E., and Portocarrero, C.: Assessment of glacier hazards and glacier runoff for different climate scenarios based on remote sensing data: a case study for a hydropower plant in the Peruvian Andes, Proc. EARSeL Workshop, Observing our cryosphere from space, Bern, Switzerland, 11.3.-13.3.2002. Paris, CD-ROM, 2003.

Huggel, C., Kääb, A., Haeberli, W., Teysseire, P., and Paul, F.: Remote sensing based assessment of hazards from glacier lake outbursts: a case study in the Swiss Alps, Can. Geotech. J., 39, 316330, 2002

Hungr, O., Morgan, G. C., and Kellerhals, P.: Quantitative analysis of debris hazards for design of remedial measures, Can. Geotech. J., 21, 663-677, 1984

Iverson, R. M., Schilling, S. P., and Vallance, J. W.: Objective delineation of lahar-inundation hazard zones, Geol. Soc. Am. Bull, 110 (8), 972-984, 1998.

Jenson, S. K. and Domingue, J. O.: Extracting topographic structure from digital elevation data for geographic information system analysis, Photogramm. Eng. Remote Sens, 54, 1593-1600, 1988.

Kääb, A.: Photogrammetry for early recognition of high mountain hazards: new techniques and applications, Phys. Chem. Earth Pt. A-Solid Earth Geod., 25, 765-770, 2000.

Kääb, A.: Monitoring high mountain terrain deformation from repeated air- and spaceborne optical data: examples using digital aerial imagery and ASTER data, ISPRS-J. Photogramm. Remote Sens, 57 (1-2), 39-52, 2002.

Kääb, A. and Vollmer, M: Surface geometry, thickness changes and flow fields on creeping mountain permafrost: automatic extraction by digital image analysis, Permafrost Periglacial Process., 11, 315-326, 2000.

Kääb, A., Paul, F., and Huggel, C.: Glacier monitoring from ASTER imagery: accuracy and applications; Proc. EARSeL Workshop, Observing our cryosphere from space, Bern, Switzerland, 11.3.-13.3.2002. Paris, CD-ROM, 2003.

Liang, L. and MacKay, D. S.: A general model of watershed extraction and representation using globally optimal flow paths and up-slope contributing areas, Int. J. Geogr. Inf. Sci., 14 (4), 337$358,2000$.

Lichtenhahn, C.: Die Verbauung des Fellbachs in der Gemeinde Saas Balen (Wallis), ETH Zürich, VAW Mitteilungen, 41, 169 176, 1979.

Lliboutry, L., Morales Arnao, B., and Schneider, B.: Glaciological problems set by the control of dangerous lakes in Cordillera Blanca, Peru, I. historical failures of morainic dams, their causes and prevention, J. Glaciol., 18 (79), 239-254, 1977.

Marks, D., Dozier, J., and Frew, J.: Automated basin delineation from digital elevation data, Geo Processing 2, 299-311, 1984.

Martz, L. W. and Garbrecht, J.: Numerical defintion of drainage network and subcatchment areas from digital elevation models, Comput. Geosci., 18 (6), 747-761, 1992.

Meissl, G.: Modellierung der Reichweite von Felsstürzen Fallbeispiele zur GIS-gestützten Gefahrenbeurteilung aus dem Bayrischen und Tiroler Alpenraum. Innsbrucker Geographische Studien, Innsbruck, 1998.

Nakagawa, H. and Takahashi, T.: Estimation of a debris flow hydrograph and hazard area, in: Debris-flow hazard mitigation: mechanics, prediction, and assess-ment; edited by Chen, C.L., Proc. 1st international conference, San Francisco, California, August 7-9, 1997, American Society of Civil Engineers, 64-73, 1997.

O'Callaghan, J. F. and Mark, D. M.: The extraction of drainage networks from digital elevation data, Computer Vision Graphics and Image Proceedings, 28, 323-344, 1984.

O'Connor, J. E. and Costa, J. E.: Geologic and hydrologic hazards in glacierized basins in North America resulting from 19th and 20th century global warming, Nat. Hazards, 8, 121- 140, 1993.

O'Connor, J. E., Hardison III, J. H., and Costa, J. E.: Debris flows from failures of Neoglacial-Age moraine dams in the Three Sisters and Mount Jefferson wilderness areas, Oregon. US Geological Survey Professional Paper, 1606, 2001.

Pietroniro, A. and Leconte, R.: A review of Canadian remote sensing applications in hydrology, 1995-1999. Hydrol. Process., 14, 1641-1666, 2000.

Popov, N.: Glacial debris flows mitigation in Kazakstan: assessment, prediction and control, in: Debris-flow hazard mitigation: mechanics, prediction, and assessment; edited by Chen, C.-L., Proc. 1st international conference, San Francisco, California, August 7-9, 1997, American Society of Civil Engineers, 113$122,1997$.

Quinn, P. F., Beven, K. J., Chevallier, P., and Planchon, O.: The prediction of hillslpoe paths for distributed hydrological modelling using digital terrain models, Hydrol. Process., 5, 59-79, 1991.

Quinn, P. F., Beven, K. J., and Lamb, R.: The $\ln (\mathrm{a} / \operatorname{tanb})$ index: how to calculate it and how to use it within the TOPMODEL framework, in: Distributed hydrological modelling, applications of the TOPMODEL concept, edited Beven, K. J., Wiley, Chichester 31-52, 1997.

Reynolds, J. M.: The identification and mitigation of glacier-related hazards: examples from the Cordillera Blanca, Peru, in: Geohazards natural and man-made, edited by McCall, G. J. H., Laming, D. J. C., and Scott, S. C., Chapman and Hall, London, 143-157, 1992.

Richardson, S. D. and Reynolds, J. M.: An overview of glacial hazards in the Himalayas, Quaternary International, 65/66, 31-47, 2000.

Rickenmann, D.: Empirical relationships for debris flows, Nat. Hazards, 19, 47-77, 1999.

Rickenmann, D. and Zimmermann, M.: The 1987 debris flows in Switzerland: documentation and analysis, Geomorphology 8, 175-189, 1993.

Röthlisberger, H.: Eislawinen und Ausbrüche von Gletscherseen, Jahrbuch der Schweizerischen Naturforschenden Gesellschaft 1978, 170-212, 1981.

Schilling, S. P. and Iverson, R. M.: Automated, reproducible delineation of zones at risk from inundation by large volcanic debris flows, in: Debris-flow hazard mitigation: mechanics, prediction, 
and assessment; edited by Chen, C.-L., Proc. 1st international conference, San Francisco, California, August 7-9, 1997, American Society of Civil Engineers, 176-186, 1997.

Tarboton, D. G.: A new method for the determination of flow directions and upslope areas in grid digtital elevation models, Water Resour. Res., 33 (2), 309-319, 1997.

Tarboton, D. G., Bras, R. L., and Rodriguez-Iturbe, I.: On the extraction of channel networks from digital elevation data, Hydrol. Process., 5 (1), 81-100, 1991.

Vuichard, D. and Zimmermann, M.: The 1985 catastrophic drainage of a moraine-dammed lake Khumbu Himal, Nepal: cause and consequences, Mt Res. and Dev., 7, 91-110, 1987.

Walder, J. S. and O'Connor, J. E.: Methods for predicting peak discharge of floods caused by failure of natural and constructed earthen dams, Water Resour. Res., 33 (10), 2337-2348, 1997.
Wessels, R. L., Kargel, J. S., and Kieffer, H. H.: ASTER measurement of supraglacial lakes in the Mount Everest region of the Himalaya, Ann. Glaciol., 34, 399-408, 2002.

Yamada, T.: Glacier lake and its outburst flood in the Nepal Himalaya, Data Center for Glacier Research, Japanese Society of Snow and Ice, Tokyo. Monograph 1, 1998.

Zimmermann, M. and Haeberli, W.: Climatic change and debris flow activity in high mountain areas; a case study in the Swiss Alps, Catena (Suppl.), 22, 59-72, 1992.

Zimmermann, M. and Lehmann, C.: Geschiebefracht in Wildbächen: Grundlagen und Schätzverfahren, Wasser, Energie, Luft, 91 (7/8), 189-194, 1999.

Zimmermann, M., Mani, P., Gamma, P., et al.: Murganggefahr und Klimaänderung - ein GIS-basierter Ansatz, Schlussbericht NFP 31, vdf Hochschulverlag, Zürich, 1997. 